\title{
Modelling routes towards learning goals
}

\author{
Citation for published version (APA):
}

Tattersall, C., Janssen, J., Van den Berg, B., \& Koper, R. (2006). Modelling routes towards learning goals. Campus Wide Information Systems, 23(5), 312-324. https://doi.org/10.1108/10650740610714071

DOI:

$10.1108 / 10650740610714071$

Document status and date:

Published: 10/01/2006

Document Version:

Peer reviewed version

Document license:

CC BY-NC-ND

Please check the document version of this publication:

- A submitted manuscript is the version of the article upon submission and before peer-review. There can be important differences between the submitted version and the official published version of record. People interested in the research are advised to contact the author for the final version of the publication, or visit the DOI to the publisher's website.

- The final author version and the galley proof are versions of the publication after peer review.

- The final published version features the final layout of the paper including the volume, issue and page numbers.

Link to publication

\section{General rights}

Copyright and moral rights for the publications made accessible in the public portal are retained by the authors and/or other copyright owners and it is a condition of accessing publications that users recognise and abide by the legal requirements associated with these rights.

- Users may download and print one copy of any publication from the public portal for the purpose of private study or research.

- You may not further distribute the material or use it for any profit-making activity or commercial gain

- You may freely distribute the URL identifying the publication in the public portal.

If the publication is distributed under the terms of Article 25fa of the Dutch Copyright Act, indicated by the "Taverne" license above, please follow below link for the End User Agreement:

https://www.ou.nl/taverne-agreement

Take down policy

If you believe that this document breaches copyright please contact us at:

pure-support@ou.nl

providing details and we will investigate your claim.

Downloaded from https://research.ou.nl/ on date: 26 Apr. 2023 


\title{
Modelling routes towards learning goals
}

\author{
Colin Tattersall, José Janssen, Bert van den Berg, Rob Koper
}

All authors are employed at the Educational Technology Expertise Centre (ETEC) of the Open University of the Netherlands. Address for correspondence: Colin Tattersall, Open University of the Netherlands, P.O. Box 2960, 6401 DL Heerlen, The Netherlands. E-mail: colin.tattersall@ou.nl.

\begin{abstract}
The traditional notion of the curriculum as a fixed list of topics to be studied sequentially is undergoing change informed by constructivist theories. However, abandoning the notion of the curriculum as a study plan raises the need to help learners in understanding both where they stand with respect to their desired competences and how these competences can be attained. This article presents a formal model for the description of routes to learning goals, designed to underpin guidance support systems for learners. The article compares the model to other work in the area, illustrates its application with a number of case studies and concludes with a discussion of the broader e-learning infrastructure required in implementing the approach.
\end{abstract}

Keywords

Curriculum design, standards, guidance, educational goals, e-learning

\section{Introduction}

The use of the internet as a delivery technology for education and training is now commonplace, with both distance and presential learning providers exploiting e-learning in their offerings. A standards-based IT infrastructure is in place in educational institutions around the world, simplifying the delivery equation and opening the doors to mainstream, large-scale, web-based education (Brusilovsky \& Vassileva, 2003).

In parallel with this major change in the delivery of education, and informed by constructivist educational theories, the nature of curriculum is undergoing reassessment. Rather than a fixed sequence of study, pre-determined by the teacher, these theories view curriculum as a process of co-development between teacher and learner (Granger, 1993; Kirkpatrick, 2001; Phelps, Hase, \& Ellis, 2005; Van den Berg, Blijleven, \& Jansen, 2004). Curriculum becomes a spectrum, extending from highly constrained situations in which all is fixed, through situations in which some room for manoeuvre is offered to learners, to open, unconstrained contexts in which sequence "emerges in the interaction between the learner and the environment" (Akhras \& Self, 2002).

With or without a pre-determined curriculum, learners are involved in sequencing their learning experiences, and may require assistance in this task. At the "constrained" end of the spectrum, the curriculum serves as an indication (or indeed an instruction) of what to do next. Here, guidance systems can provide assistance to the learner by indicating how much of the pre-determined curriculum has been completed and how much remains to be done. At the "unconstrained" end, assistance can be offered through new technologies from the social software world (Dron, 2006; Janssen et al., In press; Okada \& Zeiliger, 2003; Semet, Lutton, $\&$ Collet, 2003; Wexelblat, 1999). These technologies derive suggestions or recommendations 
for next steps, which learners are free to follow or ignore, from the interactions of others with e-learning systems.

We restrict the scope of this article to the formal and non-formal educational settings found in higher and adult education (Colley, Hodkinson, \& Malcolm, 2003; Livingstone, 2001). Here, a pre-determined curriculum is present, typically with various degrees of freedom for the learner to influence the selection and ordering of his or her learning experiences. Credit and modularisation play a central role in achieving this freedom (Brown \& Saunders, 1995; Hart \& Howieson, 2004; Moon, 1988); modular educational systems revolve around units which can be combined (i.e. sequenced) by learners to reach educational goals. However, the flipside of modularisation is complexity. Yorke (2002) highlights that "as the unitization of curricula spreads through higher education, so there is a need for greater guidance for students to navigate their way through the schemes". This point is also raised by Gledhill (1999) who notes the complexity inherent in modular programmes and the difficulties this implies for advice-giving.

All along the curriculum spectrum, guidance is needed by learners in the form of directions to progress towards the attainment of competences. This articles thesis is that a uniform approach to modelling these directions (i.e. a route modelling language) is needed to ease the development of a range of automated guidance systems in e-learning.

Four concepts are central to our work.

1. Goals are the competence levels which learners aim to attain. Although it is possible for learners to embark on an intellectual quest with no closely specified, fixed, or terminal point in mind (Brookfield, 1985), guidance issues are inherently linked to deliberate learning, i.e. learning which is intentional, with a definite, specific goal (Knapper \& Cropley, 1991).

2. There can be several different routes to the attainment of a goal; the goal of a bachelor's degree in Fine Art can be attained by following study programmes at hundreds of universities across the world.

3. Routes specify requirements to be met to achieve a goal in terms of combinations of Units of Learning (UoLs), an abstract term used to refer to any delimited piece of education or training, such as a course, a module, a lesson, etc. A route modelling language describes combinations of UoLs.

4. A learner's position is those UoLs which have already been, or can be considered to have been, completed. Processes of Recognition of Prior Learning, or Prior Learning Assessment (Breier, 2005; Starr-Glass, 2002), can lead to learners being exempted from some of the requirements associated with the attainment of a goal. In this way, we speak of a positioning process which maps the results of learners' prior learning onto a route, leading to his or her position along the route; with this in hand, it is possible to determine what remains to be done to reach the goal associated with the route.

Some support for navigating in formal and non-formal educational settings is available today, but it is often either tied to particular institutions or offers only a surface level of guidance. The PLOTEUS initiative (2006), for example, while laudable in its aims to help citizens find out information about studying in Europe, presents learners with a bewildering assortment of learning opportunities, each leading the enquirer to the vagaries of providers' websites. None of the information offered to learners is standardised or predictable, making it difficult to 
determine which goals can be reached by which routes. It is precisely this state of affairs that our work aims to improve: if the various institutes reachable though PLOTEUS used a common route modelling language to describe their offerings, guidance systems could help learners navigating within and between the various learning opportunities.

\section{Requirements for a route modelling language}

Requirements for a route modelling language can be found in the curriculum design literature (Bell \& Wade, 1993; Ertl, 2002; Glatthorn, Floyd Boschee, \& Whitehead, 2005; Van den Akker, 2003), lifelong learning policy documents (NOCN, 2004a; SCQF, 2003) and literature on credit accumulation and transfer (Adam, 2001; Gosling, 2001; Winter, 1994).

We summarise the requirements in the following points:

1. Modular composition: Routes to goals must be able to be constructed from units. Example: in order to reach competency level 3, modules $45 a, 33 d$ and $67 t$ must be successfully completed.

2. Nested composition: Routes must be able to be composed of other routes.

Example: the Course can be divided into two phases: the propedeutic phase and the post-propedeutic phase. The propedeutic phase consists of the following modules ...

3. Selection: It must be possible to specify which elements of a route are mandatory and which are optional.

Example: Students must complete module H101, and may select any two modules from H1O1, H103, H1O4 or H1O5

4. Sequencing: it must be possible to specify constraints on the order in which elements of a route are to be completed.

Example: Students must first complete module "L-A4 An introduction to linguistics", before being allowed to commence module "L-G5 Psycho-linguistics"

5. Completion: The requirements for completion of an element of a route, and of the route itself, must be able to be specified.

Example: Each module carries a specific credit value. Students need to accumulate 60 credits from the optional modules in order to progress from the propedeutic to the post-propedeutic phase.

6. Conditional Composition: It must be possible to specify conditions under which elements of a route are to be included or excluded.

Example: Applicants whose mother tongue is English are not required to complete module E101.

Example: Students who have completed the introduction to Psychology are not required to complete the History of Psychology course.

Example: Learners who do not elect to follow the statistics course are required to follow an additional introduction to algebra course in the elective phase.

Furthermore, drawing on the educational modelling approach used in (Koper, 2004; Koper \& Manderveld, 2004), we add the following generic requirements for the language:

7. Formality: the language must describe a route in a formal way, so that automatic processing is possible.

8. Interoperability: The language must support interoperability of routes so that different support systems can share and exchange information.

The latter two requirements are particularly relevant to the context of lifelong learning, where individuals' learning process cover long stretches of time, including periods of suspension and 
resumption. Learners must be supported in picking up from where they left off, and in switching to different providers; a formal, interoperable, standardised approach promotes portability of route information (so that modules completed on a route offered by a particular provider can be interchanged with modules on a route offered by another provider), sustainability of route information (so that as new versions of routes appear, learners can be automatically mapped onto comparable positions on the new versions) and comparison of route information (so that guidance systems can offer advice on alternative routes to a goal).

\subsection{Related work}

There are a number of existing approaches to specifying what needs to be done by learners to achieve educational goals. The European Credit Transfer and Accumulation System or ECTS (CEC, 2004), is a systematic way of describing the student workload required to achieve the objectives of an educational programme (e.g. 'students must accumulate a total of 60 ECTS credit points'). ECTS is, however, not a formal modelling language and does not provide a means of fully specifying routes (e.g. there are no constructs to describe sequences and selections using ECTS). The National Open College Network Credit and Qualification Framework's Technical Specification for Qualifications (NOCN, 2004b) does include the notion of Rules of Combination describing mandatory and optional units. However, as yet, no formal modelling language is used for the specification of the rules, limiting the opportunities for automated processing.

Significant research in curriculum modelling has been carried out over the years in the area of Intelligent Tutoring Systems (Baldoni, Baroglio, \& Patti, 2002; Karagiannidis, Sampson, \& Cardinali, 2001; Murray, 1998; Stern \& Park Woolff, 1998; Xu, Wang, \& Wang, 2005). While this work has a formal basis which meets the generic educational modelling requirements described above, approaches to curriculum modelling in the ITS worlds have tended to involve the modelling of conceptual domain knowledge (what is related to what in the domain) and the modelling of knowledge pre-requisites (what must be learned before what) so that automatic planning processes can perform curriculum sequencing. We view this as a far deeper and correspondingly more taxing level of modelling than is required for guidance. Rather than modelling domains, a more pragmatic approach may be to model UoLs about the domains, and to use this information during guidance.

Finally, work on the eXchanging Course-Related Information (XCRI, 2006) reference model is drawing on a number of other international initiatives, particularly from the Scandinavian countries, to define a vocabulary for describing course-related information encompassing course marketing, course quality assurance, enrolment and reporting requirements. This is interesting work in progress, albeit with a scope which is slightly different to that of the work described in this article, focusing more on institutional publication of course information to diverse audiences rather than the learner guidance problem. However, the XCRI reference model includes some facilities for modelling routes which we believe could be usefully extended with the constructs included in this article.

\section{IMS Learning Design as a route modelling language}

Another candidate for a route modelling language is IMS Learning Design (IMSLD, 2003; Koper \& Olivier, 2004; Koper \& Tattersall, 2005). IMSLD provides constructs allowing instructional designers to specify which roles should carry out which activities, with which supportive learning materials and services in order to achieve learning objectives. The bulk of the literature on IMSLD has addressed its application to the modelling of the internal structure of UoLs at a micro level for subsequent 'playing' in a Virtual Learning Environment. 
However, the specification permits varying levels of granularity of a unit of learning, referring to "any delimited piece of education or training such as courses, modules or lessons"; a (macro) unit of learning can be defined in terms of other UoLs to describe routes towards goals. Using IMSLD in this way at the macro level does not require its full sophistication, simplifying the modelling task. Such use also targets a different kind of context of use: one which compares routes expressed in IMSLD with learner positions to determine what remains to be done to reach a goal.

Given its pedigree as an educational modelling language, IMSLD would seem a suitable candidate for a route modelling language. Table 1 illustrates how the requirements identified above are met using the constructs of IMSLD.

\begin{tabular}{|l|l|}
\hline $\begin{array}{l}\text { Modular } \\
\text { composition }\end{array}$ & $\begin{array}{l}\text { A UoL can reference another UoL within an activity structure } \\
\text { through a uniform resource identifier }\end{array}$ \\
\hline Nested composition & Activity structures can be nested, thereby allowing nesting of UoLs \\
\hline Selection & $\begin{array}{l}\text { The type of an activity structure can be indicated as a selection } \\
\text { indicating that the elements of the selection may be done in any } \\
\text { order. Moreover an attribute can be specified (number-to-select) to } \\
\text { indicate how many elements of the activity structure must be } \\
\text { completed before the whole activity structure is considered complete } \\
\text { (e.g. four of the six specified possibilities, one of the seven etc). }\end{array}$ \\
\hline Sequencing & $\begin{array}{l}\text { The type of an activity structure can be indicated as a sequence } \\
\text { indicating that the elements of the selection must be done in the } \\
\text { specified order. }\end{array}$ \\
\hline Completion & $\begin{array}{l}\text { IMSLD has an expression language through which complex rules for } \\
\text { completion can be defined. }\end{array}$ \\
\hline $\begin{array}{l}\text { Conditional } \\
\text { Composition }\end{array}$ & $\begin{array}{l}\text { The expression language can also be used to describe conditions } \\
\text { based on various types of properties (of the learner, the route, etc). }\end{array}$ \\
\hline Formality & $\begin{array}{l}\text { IMSLD is described using the XML Schema formalism allowing } \\
\text { various types of processing to be brought to bear on information } \\
\text { modelled using the specification. }\end{array}$ \\
\hline Interoperability & $\begin{array}{l}\text { IMSLD is an open specification published by a consortium which } \\
\text { promotes e-learning interoperability. }\end{array}$ \\
\hline
\end{tabular}

Table 1: Matching IMS LD against the route modelling requirements

In order to illustrate the way in which IMSLD can be applied to route modelling, consider the following fictitious example route, associated with the goal of becoming a Bachelor of General Studies:

The major block of the programme consists of a module on "Philosophy", followed by the choice of two modules from "Aesthetics", "Art", "Religious Studies" or "Music". Following the major block, two alternative minor programmes are available, students either elect to study, in any order, "Biology", "Physics" and "Chemistry", or elect to study first "History" then "Geography".

Figure 1 shows a diagrammatic representation of the programme. The outer, black block represents the study programme UoL which models the route. The white boxes representing the individual, module-level UoLs. Grey boxes show the various layers of nested activity structures dealing with sequences and selections. 


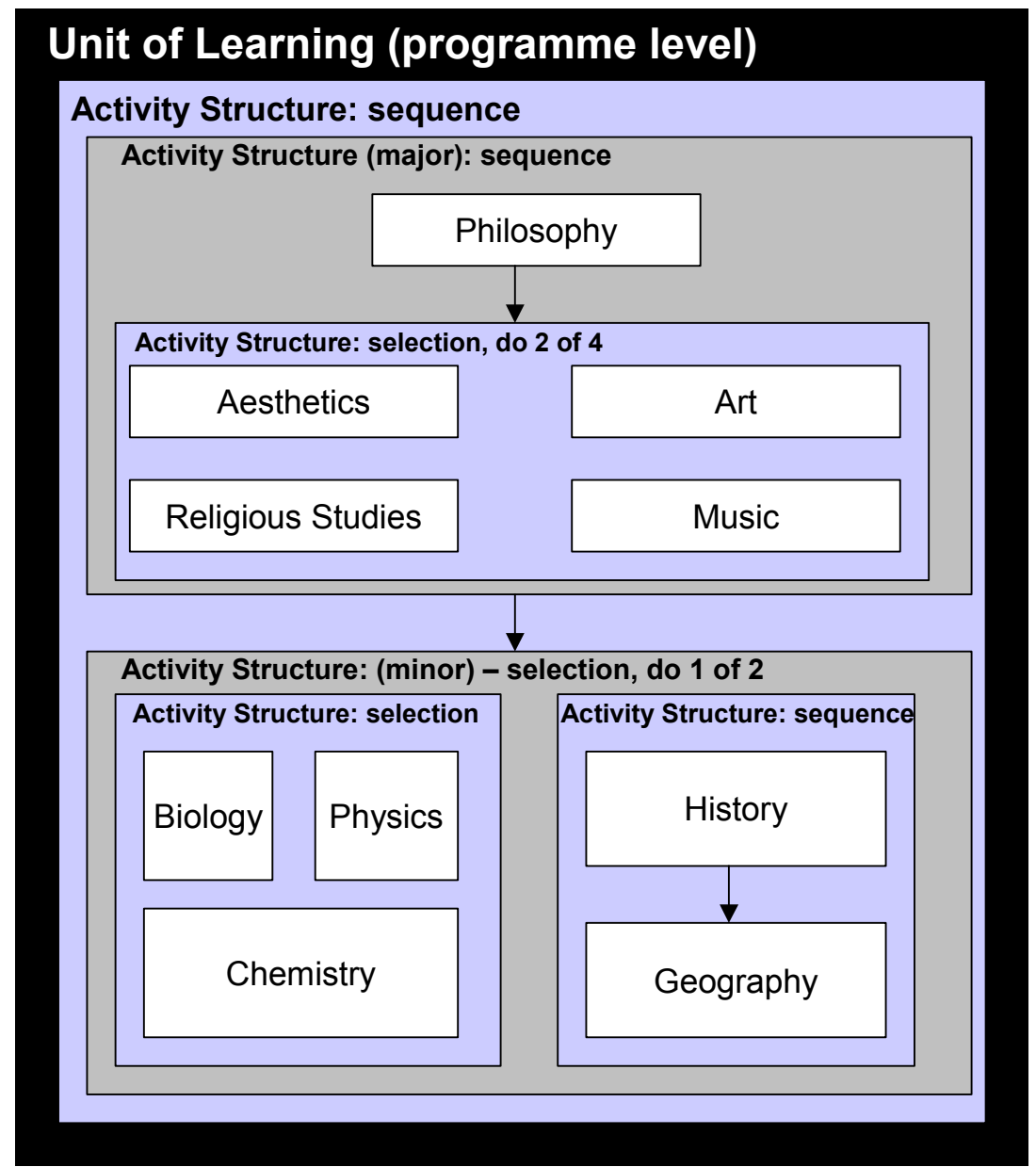

Figure 1: One route to becoming a Bachelor of General Studies

The flexibility offered in this route means that once learners have mastered Philosophy, many different combinations of modules can be followed to complete the programme and attain the associated competence level (e.g. Aesthetics, Art, History then Geography or Religious Studies, Music, Chemistry, Biology then Physics, etc).

Figure 2 shows an editor being used to create the formal IMSLD representation for the above situation. 


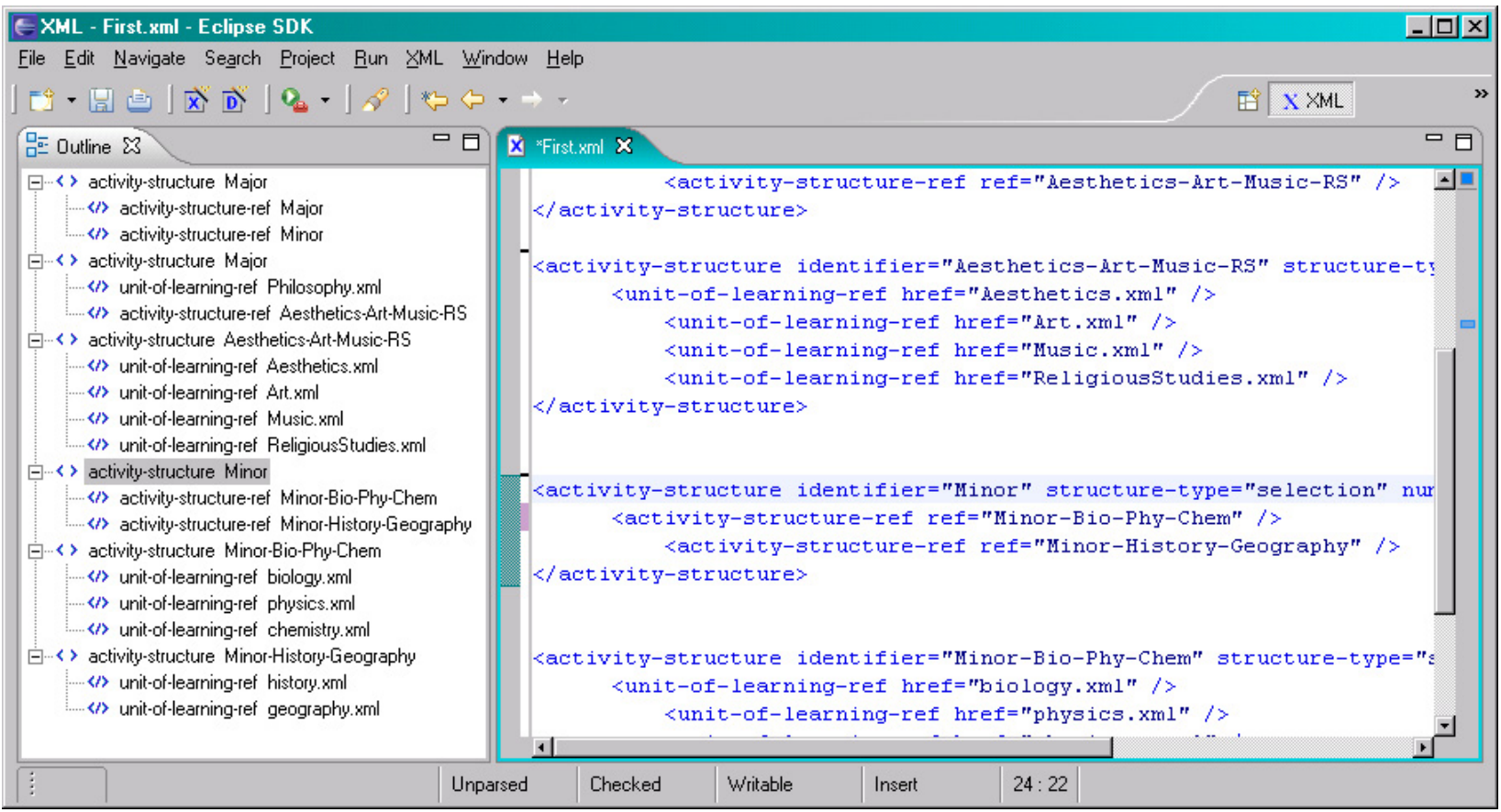

Figure 2: Representing the programme using IMSLD

\section{Case studies}

In order to investigate whether IMSLD is suitable for modelling learning routes, three sources of programmes were used. First, the distance teaching programmes offered at the Open University of the Netherlands were analysed. Second, an analysis was made of a selection of curricula found via the PLOTEUS service. Finally, a set of learning programmes which can be found on the Internet was analysed.

A sample of the results of the analysis is shown below, whereby the description of the programme is matched with a textual description of its mapping to IMSLD (XML code is excluded for clarity).

- Bachelors degree programme in Dutch Law

- The Bachelor programme in Dutch Law consists of 42 modules and is divided into two phases: the propedeutic phase (14 modules) and the post-propedeutic phase (26 modules). The former begins with an introductory course in Law (which counts for two modules) after which students follow the remaining 12 modules in any order. The modules of the post-propedeutic phase can be followed in any order. The bachelor is completed with a compulsory "integration practical" which counts for 2 modules.

- The UoL representing this route consists of an IMSLD Activity Structure (AS) which is a sequence, containing nested ASs for both the propedeutic and postpropedeutic phases, followed by a UoL representing the practical. The propedeutic phase is a sequence which starts with the UoL for the introductory course and is followed by a nested AS representing the remaining 12 modules (a selection). The post-propedeutic phase AS is a selection of the 26 modules.

- Master of Science in Psychological Research

- The programme consists of four modules which can be followed in any order, followed by a block from which 2 courses must be chosen from a selection of named research courses. 
- The master programme is modelled as an AS (sequence) of two other ASs. The first is a selection of four modules while the second is again a selection (number-to-select $=2$ ) of the research courses.

- European Computer Driving Licence, e-citizen programme (ECDL, 2006)

$\circ$ e-Citizen is the new end-user computer skills certification programme from the European Computer Driving Licence (ECDL) Foundation. The programme is designed to cater for those with a limited knowledge of computers and the Internet but who wish to gain valuable everyday computer and Internet skills. The e-Citizen Syllabus has been defined by the ECDL Foundation in three blocks which are followed in progression: Block 1: Foundation Skills, Block 2: Information Search and Block 3: E-Participation. Each block consists of a number of topics (e.g. The Computer, Files and Folders)

- A UoL is defined for each topic and grouped into an AS per block (selection). These three ASs are included in a sequence AS, ordering the blocks in the correct sequence.

- Driving Goods Vehicles National Vocational Qualification (NVQ, 2003)

- The Level 3 Qualification is for drivers who can show broader driving competencies and be considered as professional goods vehicle drivers. Drivers must obtain all 8 mandatory units, plus at least any 2 optional units from 4 specified for a full award.

- This programme again follows the pattern of two ASs, one dealing with mandatory modules (selection), the other dealing with elective modules (selection, number-to-select=2)

- University of Washington Certificate Program in Aircraft Composite Materials and Manufacturing (UoW, 2006).

- This online learning programme targets employed engineers and others who cannot take courses on campus. Coursework must be completed in order, beginning with Aircraft Composite Materials, followed by Aircraft Composite Manufacturing. Thereafter, learners choose one of two elective courses: Aircraft Composite Tooling or Aircraft Composite Repair

- This certificate programme is modelled with an AS of type sequence, which orders the first two modules, followed by a nested AS of type selection (number-to-select=1) containing UoLs representing the two elective modules

- UK National Vocational Qualification for Registered Manager (Edexcel, 2006)

- The qualification is intended for managers, assistant managers and others who have managerial responsibilities within regulated care services. All four mandatory units, one unit from each of the four optional groups and two units from any of the optional groups are required for successful completion of this $N V Q$.

- Although seemingly comparable with the examples described above, this route requires a higher degree of sophistication of IMSLD modelling. The mandatory units are dealt with using an AS of type selection. Learners' constrained picking and mixing from the four optional groups is handled using conditions. An AS containing all 16 optional modules is defined, together with a number of conditions. The conditions track whether one UoL from each group has been completed and whether 2 additional UoLs have been completed. Figure 3 shows one of the conditions being edited. 


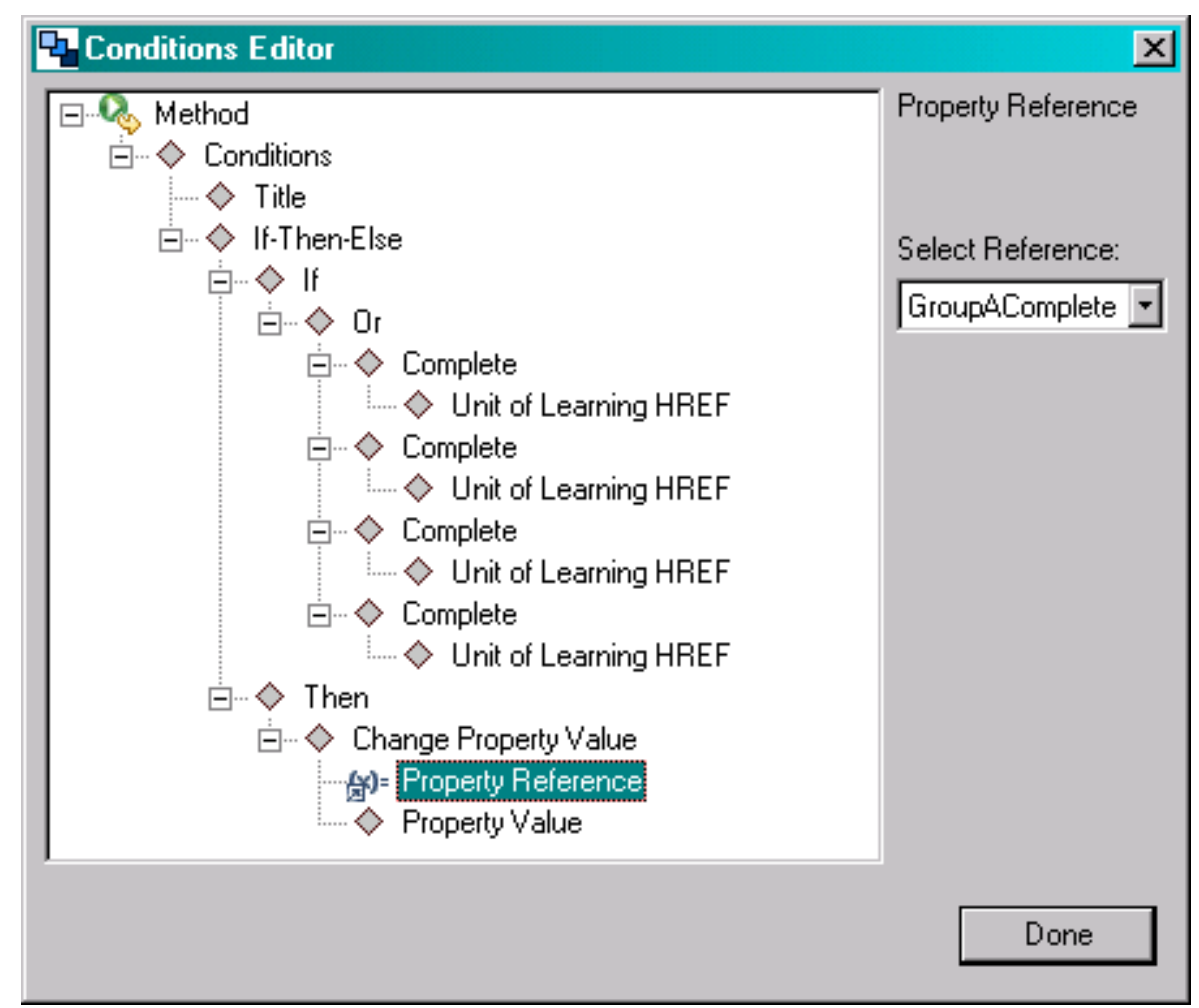

Figure 3: Setting up conditions

- B.A. in Computer Science - Systems \& Applications Computer Science (OUI, 2006).

- Students must accumulate 29 credits from the required modules and 14 credits from the elective modules. Those who have already taken Formal Automata Theory may not take Automata Theory and Formal Languages and must therefore accumulate 31 credits from required courses and 12 credits in electives in Computer Science

- The heart of this route is straightforward to model using activity structures. IMSLD conditions are, however, required first to track the ongoing accumulation of credit points (since course completion depends on a credit total rather than on a number of completed modules), as well as to adjust the total needed from the required modules depending on information on the learner's course history, excluding the relevant course (in IMSLD terms, using HIDE) appropriately.

The seven case studies cover the various route modelling requirements listed earlier in the paper.

\section{Discussion}

IMSLD's ability to sequence, select and nest various combinations of units of learning, together with its condition language provide a suitable base from which to tackle a variety of route modelling issues. Although many approaches, languages and formalisms exist in which routes could be specified (e.g. word processing documents, Java programs, HTML), IMSLD's nature as an open specification, published by non-profit organisation committed to its maintenance and with a growing set of development tools, make it an attractive solution to the route modelling problem; using it avoids the need to develop a new route modelling language to underpin learner guidance support systems. 
Clearly, adopting IMSLD as a route modelling language requires other pieces of the elearning interoperability jigsaw being in place for the approach to work:

- E-learning modules which are addressable as UoLs and able to be referenced from "route UoLs" (which can in turn be referenced from other UoLs).

- Learner record systems, or e-portfolios, so that conditions can be defined in terms of their content;

- Infrastructure to record in the above systems that a UoL has been completed, propagating this fact to associated systems;

- Agreed naming conventions for competences, again so that conditions can be created

- A route processing engine, which, given a route modelled using IMSLD and the results of a learner positioning process, is able to compute what remains to be done by the learner to reach his or her educational goal.

Further analysis is needed on the implications of route lifecycle management to confirm that IMSLD's expression language offers all the constructs needed to deal with versioning, splitting and merging of UoLs over time. In addition, a separate research strand is needed on visualising routes, positions and "to do lists" for learners, particularly in cases of complex nesting of activity structures and high degrees of optionality. Moreover, additional analysis is needed to confirm IMSLD's role in modelling “emergent routes" (the work of Rasseneur, Jacoboni, \& Tchounikine (2004) would seem to confirm this assumption).

The next step is to apply the approach in pilot learning situations built upon the appropriate infrastructure (e-portfolios, positioning services etc) to gain additional feedback on its applicability. The results of this evaluation will be reported in subsequent articles.

\section{Acknowledgements}

The authors wish to thank the management and staff of the Schloss Dagstuhl International Conference and Research Center for Computer Science for providing a pleasant, stimulating and well organised environment for the writing of this article.

\section{References}

Adam, S. (2001). A Pan-European credit accumulation framework - dream or disaster? Higher Education Quarterly, 55(3), 292-305.

Akhras, F. N., \& Self, J. A. (2002). Beyond intelligent tutoring systems: Situations, interactions, processes and affordances. Instructional Science, 30(1), 1-30.

Baldoni, M., Baroglio, C., \& Patti, V. (2002). Supporting Users in Adaptive Web-based Applications: Techniques from Reasoning about Actions. Paper presented at the WOA 2002, Milan, Italy,.

Bell, G. H., \& Wade, W. (1993). Modular Course Design in Britain: Some Problems, Issues and Opportunities. Journal of Further and Higher Education, 17(1), 3-12.

Breier, M. (2005). A disciplinary-specific approach to the recognition of prior informal experience in adult pedagogy: 'rpl' as opposed to 'RPL'. Studies in Continuing Education, 27(1), 51-66.

Brookfield, S. (1985). Self-Directed Learning: A Critical Review of Research. In S. Brookfield (Ed.), Self-Directed Learning: From Theory to Practice (Vol. 25). San Francisco: Jossey-Bass Inc.

Brown, S., \& Saunders, D. (1995). The challenges of modularization. Innovations in Education and Training International,, 32(2), 96-105. 
Brusilovsky, P., \& Vassileva, J. (2003). Course sequencing techniques for large-scale webbased education. International Journal of Continuing Engineering Education and Lifelong Learning, 13(1/2), 75-94.

CEC. (2004). ECTS Users' Guide: European Credit Transfer And Accumulation System And The Diploma Supplement. Retrieved September 29th, 2004, from http://europa.eu.int/comm/education/programmes/socrates/ects/guide en.pdf

Colley, H., Hodkinson, P., \& Malcolm, J. (2003). Informality and Formality in Learning. Retrieved August 22nd, 2005, from http://www.lsda.org.uk/files/pdf/1492.pdf

Dron, J. (2006). The way of the termite: a theoretically grounded approach to the design of elearning environments. International Journal of Web Based Communities, 2(1), 3 - 16.

ECDL. (2006). e-Citizen Syllabus Version 1.0, from http://www.ecitizen.co.uk/syllabusguide.pdf

Edexcel. (2006). National Vocational Qualifications in Registered Manager (Adults) at level 4. Retrieved January 19th, 2006, from http://hsc.edexcel.org.uk/VirtualContent/89598/NVQ_L4_RegisteredManagers_Adult leaflet.pdf

Ertl, H. (2002). The Concept of Modularisation in Vocational Education and Training: the debate in Germany and its implications. Oxford Review of Education, 28(1), 53-73.

Glatthorn, A. A., Floyd Boschee, F., \& Whitehead, B. M. (2005). The Nature of Curriculum: Sage Publications, Inc.

Gledhill, J. M. (1999). Managing Students. Buckingham: Open University Press.

Gosling, D. (2001). Lost Opportunity: What a Credit Framework Would Have Added to the National Qualification Frameworks. Higher Education Quarterly, 55(3), 270-284.

Granger, D. (1993). Reflections on Curriculum as Process. In T. E. D. Nation (Ed.), Reforming Open and Distance Education. London: Kogan Page.

Hart, J., \& Howieson, C. (2004). Unitisation - Benefits and Issues. Glasgow: Scottish Qualifications Authority.

IMSLD. (2003). IMS Learning Design Specification. Retrieved February 27th, 2004, from http://www.imsglobal.org/learningdesign/index.cfm

Janssen, J., Tattersall, C., Waterink, W., Van den Berg, B., Van Es, R., Bolman, C., et al. (In press). Self-organising navigational support in lifelong learning: how predecessors can lead the way. Computers \& Education.

Jongbloed, B. (2002). Lifelong learning: Implications for institutions. Higher Education, 44, 413-431.

Karagiannidis, C., Sampson, D., \& Cardinali, F. (2001). Integrating Adaptive Educational Content into Different Courses and Curricula. Educational Technology \& Society Journal, Special Issue on Curriculum, Instruction, Learning and the Internet, 4(3), 3744.

Kirkpatrick, D. (2001). Who Owns the E-learning Curriculum? Paper presented at the Victoria University of Technology E-learning: Ethics and Equity Conference, Melbourne.

Knapper, C. K., \& Cropley, A. J. (1991). Lifelong Learning and Higher Education (Second Edition ed.). London: Kogan Page.

Koper, R. (2004). Use of the Semantic Web to Solve Some Basic Problems in Education: Increase Flexible, Distributed Lifelong Learning, Decrease Teacher's Workload. Journal of Interactive Media in Education, Special Issue on the Educational Semantic Web(6).

Koper, R., \& Manderveld, J. (2004). Educational modelling language: modelling reusable, interoperable, rich and personalised units of learning. British Journal of Educational Technology, 35(5), 537-551. 
Koper, R., \& Olivier, B. (2004). Representing the Learning Design of Units of Learning. Educational Technology \& Society, 7(3), 97-111.

Koper, R., \& Tattersall, C. (2005). Learning Design: A Handbook on Modelling and Delivering Networked Education and Training (Vol. Heidelberg): Springer Verlag.

Livingstone, D. W. (2001). Adults' informal learning: definitions, findings, gaps and future research. Retrieved August 22nd, 2005, from http://www.oise.utoronto.ca/depts/sese/csew/nall/res/21adultsifnormallearning.htm

Moon, B. (1988). Modular Curriculum. London: Paul Chapman Publishing Ltd.

Murray, T. (1998). A Model for Distributed Curriculum on the World Wide Web. Journal of Interactive Media in Education, 5.

NOCN. (2004a). NOCN Credit and Qualification Framework Technical Specification General. Retrieved October 3rd, 2005, from http://www.nocn.org.uk/quals/qualdocs/NOCN\%20CQF\%20-\%20Technical\%20Specification \%20-\%20General $\% 20$ \%20V2.pdf

NOCN. (2004b). NOCN Credit and Qualification Framework Technical Specification Qualifications. Derby: National Open College Network.

NVQ. (2003). Industry Qualifications - National and Scottish Vocational Qualifications: Driving Goods Vehicles. Retrieved January 19th, 2006, from http://www.careersinlogistics.co.uk/uploaded_files/Documents/electronic_dgv_leaflet. pdf

Okada, A., \& Zeiliger, R. (2003). The Building of Knowledge through Virtual Maps in Collaborative Learning Environments. Paper presented at the ED-MEDIA 2003 conference, Hawaii, USA.

OUI. (2006). Requirements for interdisciplinary degrees: B.A. in Education (Curriculum \& Instruction Studies) and Computer Science - Systems \& Applications. Retrieved January 19th, 2006, from http://www-e.openu.ac.il/program_of_study/28.htm

Phelps, R., Hase, S., \& Ellis, A. (2005). Competency, capability, complexity and computers: exploring a new model for conceptualising end-user computer education. British Journal of Educational Technology, 36(1), 67-84.

PLOTEUS. (2006). Portal on Learning Opportunities throughout the European Space. Retrieved January 19th, 2006, from http://europa.eu.int/ploteus

Rasseneur, D., Jacoboni, P., \& Tchounikine, P. (2004). Using and Enhancing a Normalized IMS-LD Description to Support Learners in their Appropriation of a DistanceLearning Curriculum. Paper presented at the IEEE International Conference on Advanced Learning Technologies (ICALT'2004), Joensuu, Finland.

SCQF. (2003). An Introduction to the Scottish Credit and Qualifications Framework, 2nd Edition.

Semet, Y., Lutton, E., \& Collet, P. (2003, April 24-26, 2003). Ant Colony Optimisation for ELearning: Observing the Emergence of Pedagogic Suggestions. Paper presented at the SIS'03: IEEE Swarm Intelligence Symposium, Indianapolis, Indiana, USA.

Starr-Glass, D. (2002). Metaphor and totem: Exploring and evaluating prior experiential learning. Assessment \& Evaluation in Higher Education, 27(3).

Stern, M., \& Park Woolff, B. (1998). Curriculum Sequencing in a Web-Based Tutor. Paper presented at the 4th International Conference on Intelligent Tutoring Systems.

UoW. (2006). University of Washington Certificate Program in Aircraft Composite Materials and Manufacturing. Retrieved January 19th, 20036

Van den Akker, J. J. H. (2003). Curriculum perspectives: an introduction. In J. van den Akker, W. Kuiper \& U. Hameyer (Eds.), Curriculum landscape and trends. Dordrecht: Kluwer Academic Publishers. 
Van den Berg, E., Blijleven, P. J., \& Jansen, L. M. (2004). Digital learning materials: classification and implications for the curriculum. In J. Van den Akker, Kuiper, W. \& Hamayer, U. (Ed.), Curriculum landscapes and trends. Dordrecht: Kluwer Academic Publishers.

Wexelblat, A. I. p. (1999). Footprints: History-Rich Tools for Information Foraging. Paper presented at the Proceedings of Conference on Human Factors in Computing Systems (CHI'99), Pittsburgh.

Winter, R. (1994). The problem of educational levels (part 2): a new framework for credit accumulation in higher education. Journal for Further and Higher Education, 18(1), 92-106.

XCRI. (2006). eXchanging Course-Related Information. Retrieved January 16th, 2006, from http://www.elframework.org/projects/xcri

Xu, D., Wang, H., \& Wang, M. (2005). A conceptual model of personalized virtual learning. environments. Expert Systems with Applications,, 29(3). 